Reseña

\section{Concha Betrán and Maria A. Pons (eds.). Historical Turn- ing Points in Spanish Economic Growth and Development, 1808-2008. Palgrave, 2020, 267 pp. ISBN: 978-3030409098; 978-3030409104 (ebook).}

Turning points, argue Concha Betrán and Maria A. Pons-the editors of this timely book-, alter the rules, the institutional framework and the attitudes that, up to that point, have underpinned a country's past. As this book was going to press, the world, including Spain, was entering into what seems to be yet another historical turning point. Even if it is too early to say, the differential toll that the Covid-19 crisis is likely to leave in Spain, as several previous crises have done, will unveil deep structural economic and institutional weaknesses. Understanding the origins of these weaknesses requires the challenging task of getting familiar with the country's recent past and the way its institutions, its political class and its population have reacted to the main economic shocks and defining moments of Spanish contemporary economic history. This book takes the challenge, and puts together the main events in economic, institutional and political history of 200 years spanned over three centuries.

The book starts with the first of the two turning points that the authors locate in the $19^{\text {th }}$ Century. Francisco Comín describes the impact of the Napoleonic Wars and the loss of the American Colonies, and marks the turning point in 1808 , the year of the Napoleonic invasion of Spain and the outbreak of the War of Independence. This chapter is the one that covers the longest period, not only because Comin provides substantial pre-1808 context but also because it goes well into the second half of the $19^{\text {th }}$ century. It considers short- and longterm effects separately, which helps disentangle the first demographic, agrarian and political impact, from the deeper institutional changes, namely the (discontinuous) process of economic liberalization. The chapter connects these fundamental institutional changes to current debates on the origins of the fiscal state and fiscal capacity, the long-term evolution of taxation, financial development, and the importance of backward linkages for industrial development.

Next, Pablo Martín-Aceña and Inés Roldán de Montaud focus on 1898, the year Spain lost Cuba, Puerto Rico and the Philippines. The chapter extends well into the $20^{\text {th }}$ Century, providing the reader with a comprehensive picture of the years of relative economic apathy that followed 1898 . The authors explain the short term industrial consequences but perhaps more importantly, in terms of structural turning points, the way in which industrial cores adapted to a new scenario where a strong reliance on colonial markets for exports was no longer an option. They also provide a discussion of the monetary consequences of Spain's military defeat, focusing on how mon- etary and fiscal authorities financed the war and how subsequent monetary disorder lay the foundations of a new macroeconomic regime-a sharp fiscal consolidation and monetary contraction-that would last until the outbreak of the First World War.

The main turning points of the $20^{\text {th }}$ century are then addressed in three different chapters. First, Concha Betrán deals with the outbreak of the Spanish Civil War in 1936. The chapter aims at contextualizing the Spanish experience during the Great Depression. In doing so, the chapter sheds a remarkable amount of light in the antecedents and the path to July 1936, focusing on the determinants of the comparative impact of the Great Depression in Spain and the main political and social reforms brought about by the Second Spanish Republic from 1931 as well as the constraints on economic policy and political reform. As opposed to the previous chapters, and much to the benefit of the reader, Betrán chose to focus more on the years before the war, rather than on its long term consequences.

The second chapter on the $20^{\text {th }}$ century uses some of the room left by the previous chapter and, despite it places its turning point in the Stabilization Plan of 1959, it helps the reader to find, in the 1940s and early 1950s, some of the structural consequences of the Civil War and the first years of Franco's Dictatorship. In this chapter, Elena Martínez-Ruiz and Maria A. Pons, provide a thorough analysis of the motivations, the mechanisms and the political constraints of the reforms that initiated the so-called "Second Francoism" (1959-1975), the period in which Spain started to recover some of the lost ground during the Civil War and the "First Francoism" (19391959). While focused on 1959 reforms for reducing macroeconomic imbalances, the chapter also provides a critical approach to the achievements of the post-1959 period in terms of institutional change, highlighting the limits and the actual scope of the changes introduced by the regime, as well as an international comparative perspective vis-à-vis Europe and Latin America.

In the last chapter dealing with the $20^{\text {th }}$ century Joaquim Cuevas and Maria A. Pons focus on 1977, the year of the delayed reckoning of the structural imbalances inherited from Franco's dictatorship and that pushed Spanish economic and social agents to agree on structural reforms in the so-called Pactos de la Moncloa. The chapter is perhaps the densest, as it is inevitably populated with specific political events, key elements of economic and political reforms, government changes, labour market regulation and all against the backdrop of the political and social Transition towards democracy. The chapter will help the reader understand the origins of some of the relative weaknesses of Spain's labour market, fiscal capacity and tax system, as well as their political economy aspects. 
The book closes with 2008. In a similar spirit as the previous chapter, Jose Ignacio Conde-Ruiz and Elena Martínez-Ruiz highlight the impact of the Great Financial Crisis as a sudden realization of the protracted structural deficiencies of the Spanish economy; starting from Spain's macroeconomic adjustments to fulfil Maastricht requirements and the entry into the EMU, the authors discuss labour market reforms, growing regional political conflict, the rapid expansion of the banking system and the political capture of savings banks and Spain's excessive reliance on real estate as a driver of economic growth and employment pre-2008. The authors place the turning point in 2008 , and not in 2012 , when the country was on the verge of default and required assistance from European institutions. This decision effectively gives more weight to the international dimension of the crisis rather than the inevitable realization of Spain's idiosyncratic political and economic problems from 2012 onwards, something that highlights the role of Spain's integration in the global economy-a common thread through all chapters-, its peripheral role and the strong domestic impact of international shocks.

Defining specific turning points in history is a challenging and potentially costly task. This book tackles the challenge, showing that it is one worth taking, and does so in 250 odd pages. It is written with the international reader in mind, which requires hitting the right balance between synthesis and context, something the authors have achieved. Overall, this is an important contribution and a laudable synthesis exercise that will certainly serve as the starting point for current and future researchers interested in learning more about contemporary Spanish economic history.

Enrique Jorge-Sotelo Universitat de Barcelona

https://doi.org/10.33231/j.ihe.2021.09.004 